Egypt. Acad. J. Biolog. Sci., 4(1): 247-253 (2012) (Review Article) B. Zoology

Email: egyptianacademic@yahoo.com

ISSN: 2090 - 0759

Received: $29 / 11 / 2012$

www.eajbs.eg.net

\title{
Preliminary studies on evolutionary of genetic markers in the salmonid species
}

\author{
*Abolhasan Rezaei \\ *Department of Genetics-School of Basic Science, Tonekabon Branch, Islamic Azad \\ University, Tonekabon, Iran. \\ Mailing Address: Islamic Azad University Tonekabon Branch-Iran. P.O. Box \\ 4864161187, Tonekabon, Iran. \\ a.rezaei@tonekaboniau.ac.ir
}

\section{ABSTRACT}

This study deals with evolutionary genetics of salmonids populations, with the special emphasis on the roles of migration, random genetic drift, mutation, and natural selection affecting the patterns of molecular variation across contemporary and historical time scales.

Studies of nuclear DNA and mitochondrial genomic variation supported the hypothesis that salmonid populations differ from the geographical regions, indicating for genetic diversity between populations. This study were used some genes for nuclear DNA genomic and mitochondrial DNA genomic for evaluation of the rate diversity. We suggest that the region of geographically is important to rate of diversity between and within populations. Were used marker genetic techniques such as the microsatellites markers, SNPs, RFLP, and some genes from mitochondrial genomic that engaged on the rate of diversity in populations of salmonids. Between and within population of $S$. salar and $S$. trutta were found single mutation by SNPs technique. RFLP analysis by nuclear DNA genomic such as microsatellites and growth hormone gene and also mitochondrial DNA genomic as cytochrome $b$ and 12S rRNA gene and markers also showed the low variation between and within salmonids populations.

Keywords: Salmonids populations, Evolutionary genomic, Mitochondrial genomic.

\section{INTRODUCTION}

\section{Salmon types and its life cycle}

Salmonids family constitutes one of the most manipulated fish in temperate countries. Moreover, they are living from Eurasia to North Africa that their behaviors are migrated from Sea to rivers that including specialization for anadromous, fluviatile and lacustrine ecological modes of life (Behnke, 1968; Hamilton et al., 1989; Hindar et al., 1991). According to theory of Professor Berg (1948), Salmonids belongs to the phylum Chordata (the chordates), the class Osteichthyes (the bony fishes), the order Salmoniformes, the family Salmonidae and genus of Salmon. In the Salmonid species, there are specially fishes such as Salmo Salar (Atlantic salmon) lives in Europe and North America can live up to 15 years and can reach a length of $150 \mathrm{~cm}$ and a weight up to $50 \mathrm{~kg}$ (Klemetsen et al. 2003).

S. salar exhibit a remarkable phenotypic plasticity and variations of its life cycle that allow it to adapt to the varied temperate biogeography and seasonal climate. S. salar exists in both anadromous (migratory) and landlocked (freshwater) forms. Together with the Rainbow trout (Oncorhynchus mykiss) it is one of the most intensively studied fish species in a wide range of research areas (Thorgaard et al., 
2002; Rise et al., 2004). As most salmonid species, S. salar is divided into geographically distinct units that are more or less isolated from each other.

Numerous studies have demonstrated that salmonids species have distinct populations on the river or tributary basis (McConnell et al., 1995a; Sanchez et al., 1996; Koljonen et al., 1999; Verspoor et al., 1999; Spidle et al., 2001; King et al., 2001). Brown trout, Salmo trutta fario and Salmo trutta caspius belong to the nine subspecies of Salmo trutta in the world (Quillet et al., 1992). These species live in the North of Europe and America, the Southern Caspian Sea and its tributaries respectively (Quillet et al., 1992). This species is critically endangered anadromous. Hence, salmonid species have more importance in industry of aquaculture for studies of their behavior and genetics distant. Hence, these species are very rare in the world. In this study we aimed to discuss about relationship, origin ancient and the rate of the variation genetics between salmonids.

Studies of the evolution of DNA genomic in the salmonids:

Studies on the evolution of genomic DNA have been investigated on the nuclear genomic DNA and mitochondrial DNA genomic markers. The DNA genomic marker is exclusively parental traits and mtDNA sequences are almost exclusively maternally inherited (Gyllensten et al., 1985). There is a lot of sequence marker for the investigation of an ancient inheritance that reported by scientists. They defined as a change in allele frequencies over time. A fundamental goal of evolutionary biology is to better understand how natural selection operates in interaction with other evolutionary processes such as mutation, migration, and random genetic drift. Determination of the relative roles of single evolutionary forces that affect the genetic variation across genomes or populations is a challenging task, particularly because researchers usually depend on observations of the patterns of genetic variation within and between populations or species, to infer the dynamic processes that could not be directly observed (Lewontin, 2002). In salmonids we had very rapid growth of sequence information (Bayne et al., 2001; Davey et al., 2001; Thorgaard et al., 2002; Martin et al., 2002; Rise et al., 2004; Tsoi et al., 2004). We offer an exciting possibility to evaluate the relative roles of different evolutionary factors. Here we discussed about some molecular markers that engaged in the evolution of salmonids.

Polymorphism in Salmonids:

Mini and microsatellites: Mini and microsatellites in fact are tandemly repeated DNA sequences are 1-6 and 10-100 base pairs in the length respectively and are common throughout the nuclear genomes of eukaryotes (Jarne \& Lagoda 1996). Microsatellite markers can be used to determine the population structure within and among populations (Wang et al., 2009a). Evaluations of population differentiation permit the estimation of the migration rate between populations, assuming that these populations are in equilibrium (e.g., no selection, identical mutation rates and generation time) (Weising et al., 2005).

The advantage of these tandem repeat markers stems for their very high variability which enables to efficiently apply them both at individual and population level analysis (Waser \& Strobeck 1998; Manel et al., 2003; Hedrick, 1999; Balloux et al., 2000; Moss, Piertney \& Palmer, 2003). Usually, tandem repeat markers are considered as evolutionary neutral DNA markers (Li et al., 2002). However, selection can affect the nearby flanking neutral variation, known as genetic hitch-hiking (Maynard-Smith \& Haig, 1974).

In Salmonids, specially S. Salar, Terauchi and Knuma, 1994; Watkins et al, 1995, had reported that the level of heterozygosity observed in the four microsatellite loci the higher may be attributed to a much larger number of alleles at each locus 
(0.829) and the mean heterozygosity were observed (0.69), it was observed that were a significant variation between and within populations (Devlin et al., 1993). Hence we can conclude in salmonids, especially S. Salar populations there were high degree polymorphism and genetic variability at the alleles of microsattelites between and within populations, however in other species of salmonids, individually S.trutta no genetic differentiation was found between populations (Todd et al. 2004).

Single nucleotide polymorphism ( SNPs):

The vertebrate genome there is a variation polymorphism by SNPs, and their application as genetic markers are known for studies of the molecular genetic variation within and between populations. Recently were used the application of SNPs in studies of molecular variation in salmonids. Studies on the salmonids were used especially on the S. Salar, S. trutta and Oncorhynchus mykiss. Hayes et al. (2005) proposed that the sequences of SNPs, could in fact be a consequence of ancient duplication events in the salmonids genome that actually could sequence difference between ancestral duplicates. In fact the result of this study found high variation about SNPs polymorphism between and within salmonids. However the rate of variation between salmonids is different, for ex. in $S$. salar populations a lower nucleotide diversity showed (Hayes et al., 2005), in opposite that, Bernatchez 2001 proposed that the highest level of diversity were observed in $S$. trutta populations. Hence is difficult to explain as all individual analysis originates from the same evolutionary lineage (the Atlantic lineage). However the population of Finnish $S$. trutta was assessed in the study of Bernatchez et al., 2001.

\section{Restriction fragment length polymorphism (RFLP):}

RFLP from nuclear DNA genomic has been used for identity of the ancient salmonids. There were some genes for studies of the RFLP techniques, individually growth hormone (GH) gene. The GH gene has been studied by (Agellon et al., 1988; Rentier-Delrue et al., 1989; Gross and Nilsson 1995; Rezaei et al., 2011). The salmon types including S. Salar, S. trutta and S.t. caspius, that selected from 1825 bp. from full length of S. salar and 2048 bp. from S.t. caspius. The results showed, there were high homology between sequences of GH genes in the Salmonids.

\section{Mitochondrial DNA genomic variation:}

The complete DNA mitochondrial genomic contains thirteen coding gene, twenty two transfer RNAs (tRNA), two ribosomal RNAs (rRNAs) and one noncoding region that commonly known as the displacement loop (D-loop) in vertebrates. The complete sequence of mitochondrial genomic in S. Salar, S. trutta and Oncorhynchus mykiss was around 16600 bp. in the length, had deposited in GenBank database, that including sense and nonsense coding region. Studies on the mitochondrial genomic had done one by one gene of mitochondrial and also by RFLP methods for genes of the mitochondrial.

Futoshi Aranishi et al., 2005, proposed that the PCR-based technique developed in the study of economically important species of salmonids (Alaska pollack, Pacific cod and Atlantic cod). RFLP analysis of cytochrome b gene by direct double enzyme digestion of the unpurified PCR products proved to be a simple, reliable and rapid method showed no nucleotide mutation was found at the recognized sites of both restriction enzymes. mtDNA lineages also studied by (Bernatchez et al., 1992) on the brown trout by using of the Alu I restriction enzyme could cut the mtDNA control region at a length of about 1050 bp for two different restriction profiles. In all samples Alu I cut the control region in four places and formed five fragments of lengths of 464, 311, 252, 37 and $4 \mathrm{bp}$. The results showed that there were low genetic diversity between populations. 
The cytochrome b and 12s ribosomal RNA was designed based on consensus sequences detected on different fish mitochondrial genomes extracted from the GenBank database. Following digestions, distinct single restriction enzyme patterns or mtDNA haplotypes were used by specific restriction enzymes. Were identified that 4 different native brown trout genotypes. All these hatchery genotypes were distributed across tributaries under restocking act. The genetic diversity associated with their populations (Bernatchez et al., 1992).

Cytochrome b in s. t. fario also were sequenced (1191 bp ) by Rezaei, 2011, He had reported that there were high homology between s. t. fario and other salmonids such as s. salar and s. t. caspius populations (Rezaei and Akhshabi, 2011; Rezaei et al., 2011; Rezaei and Akhshabi, 2012; Rezaei et al., 2012; Rezaei 2012a; Rezaei 2012b).

\section{CONCLUSION}

The present study was used differences in trait association of the genetic markers may exist in different populations of salmonids. More tests are needed in other populations of bony fishes to variety-associated effects of genetic marker, on the ancient of the salmonids in the mitochondrial and nuclear DNA genome. However, the mitochondrial gene traits and nuclear genes in salmonids have been varied between and within populations but also studies on the phenotypic and geography is necessary. Hence these parameters are affected on polymorphism of the salmonids. We suggest that the region of geographically is important for rate of diversity between and within populations however the species of salmonids were same.

\section{ACKNOWLEDGMENTS}

This work was financially supported by the Research Council of Islamic Azad University Tonekabon Branch, Iran.

\section{REFERENCES}

Agellon L.B., Davies S.L., Chen T.T. and Powers D.A. (1988). Structure of a fish (rainbow trout) growth hormone gene and its evolutionary implications. Proc. Natl. Acad. Sci. U.S.A., 85: 5136-5140.

Balloux F., Brunner H., Lugon-Moulin N., Hausser J. and Goudet J. (2000). Microsatellites can be misleading: An empirical and simulation study. Evol., 54: 1414-1422.

Bayne C.J., Gerwick L., Fujiki K., Nakao M. and Yano T. (2001). Immune-relevant (including acute phase) genes identified in the livers of rainbow trout, Oncorhynchus mykiss, by means of suppression subtractive hybridization. Dev. Com. Imm., 25: 205-217.

Berg L. S. (1948). Freshwater fishes of the USSR and adjacent countries. Zoological Institute Akademy Nauk Moscow USSR., 1(27):1.

Behnke R. J. (1968). A new subgenus and species of trout, Salmo (Platysalmo) platycephalus from south central Turkey, with comments on the classification of the subfamily Salmonidae. Mitteilungen hamburgisches zoologisches Mus. Inst, 66: 1-15. 
Bernatchez L. (2001). The Evolutionary History of Brown Trout (Salmo trutta L.) Inferred from Phylogeographic, Nested Clade, and Mismatch Analyses of Mitochondrial DNA Variation. Evol., 55: 351-379.

Bernatchez L., Guyomard R. and Bonhomme F. (1992). DNA sequence variation of the mitochondrial control region among geographically and morphologically remote European brown trout Salmo trutta populations. Mol. Eco., 1: 161-173.

Davey G.C., Caplice N.C., Martin S.A. and Powell R. (2001). A survey of genes in the Atlantic salmon (Salmo salar) as identified by expressed sequence tags. Gen., 263: 121-130.

Devlin R.H. (1993). Sequence of sockeye type 1 and type 2 growth hormone genes and the relationships of rainbow trout with Atlantic and Pacific salmon. Can. J. Fish. Aquat. Sci., 50: 1738-1748.

Douglas S.E. (2004). Identification of Immune-Relevant Genes from Atlantic Salmon Using Suppression Subtractive Hybridization. Mar. Bio., 6:199-214.

Futoshi A., Takane O. and Shotaro, I. (2005). Identification of gadoid species (Pisces, Gadidae) by PCR-RFLP analysis. J. Appl. Gen., 46(1):69-73.

Gross R. and J. Nilsson. (1995). Application of heteroduplex analysis for detecting variation within the growth hormone 2 genes in (Salmo trutta L.) brown trout. Her., 74: 286-295.

Guyomard, R., Diversite genetique de la truite commune.(1989). Bull. Fr. Peche Piscic, 314: 118-135.

Gyllensten U, Wharton D. and Wison AC. (1985). Maternal inheritance of mitochondrial DNA during back-crossing of two species of mice. J. Her., 76: 321-24.

Hinder K., N. Ryman and Utter F. (1991). Genetic effect of cultured fish on natural fish populations. Can. J. Fish. Aquat. Sci., 48: 945-957.

Hamilton K.E., Ferguson A., Taggart J.B., Tomason T., Walker A. and Fahy E. (1989). Post-glacial colonization of brown trout, Salmo trutta L.: LDH-5 as a phylogeographic marker. J.F. Bio., 35:651 -664.

Hayes B., Sonesson A.K, Gjerde B. (2005). Evaluation of three strategies using DNA markers for traceability in aquaculture species. Aqua., 250:70-81.

Hedrick P.W. (1999). Perspective: Highly variable loci and their interpretation of evolution and conservation. Evol., 53: 313-318.

Jarne P. and Lagoda P.J.L. (1996). Microsatellites, from molecules to populations and back.T. Eco. Evol., 11: 424-429.

Klemetsen A., Amundsen P.A., Dempson J.B., Jonsson B., Jonsson N., O'Connell M.F. and Mortensen E. (2003). Atlantic salmon (Salmo salar L.), brown trout (Salmo trutta L.) and Arctic charr (Salvelinus alpinus L.) a review of aspects of their life histories. Eco. F. F., 12: 1-59.

King T.L., Kalinowski S.T., Schill W.B., Spidle A.P. \& Lubinski B.A. (2001). Population structure of Atlantic salmon (Salmo salar L.): a range-wide perspective from microsatellite DNA variation. M. Eco., 10: 807-821.

Koljonen, M.L., Jansson H., Paaver T., Vasin O. and Koskiniemi J. (1999). Phylogeographic lineages and differentiation pattern of Atlantic salmon (Salmo salar) in the Baltic Sea with management implications. C. J.F.A. S., 56: 17661780.

Li Y.C., Korol A.B., Fahima T., Beiles A. and Nevo E. (2002). Microsatellites: genomic distribution, putative functions and mutational mechanisms: a review. M. E., 11: 2453-2465.

Lewontin R.C. (2002). Directions in evolutionary biology. A.R.G., 36: 1-18. 
McConnel S.K., O'ReïIly P., Hamilton L., Wright J.M. and Bentzen P. (1995a). Polymorphic microsatellite loci from Atlantic salmon (Salmo salar)Genetic differentiation of North American and European populations. Can J. Fish Aqu. Sci., 52: 1863-1872.

Manel S., Schwartz M.K., Luikart G. and Taberlet P. (2003). Landscape genetics: combining landscape ecology and population genetics. T. E.E., 18:189-197.

Maynard Smith J. and Haigh J. (1974). The hitch-hiking effect of a favourable gene. G.R., 23: 23-35.

Martin S.A., Caplice N.C., Davey G.C. \& Powell R. (2002). EST-based identification of genes expressed in the liver of adult Atlantic salmon (Salmo salar). Bio.B. R. C., 293:578-585.

Moss R., Piertney S.B. and Palmer S.C.F. (2003). The use and abuse of microsatellite DNA markers in conservation biology. W. B., 9:243-250.

Rezaei A. and Akhshabi S.H. (2011). Evolutionary Genetic Analysis of the cytochrome b gene variation in the Salmo trutta fario with other salmons. Egypt. Acad. J. biolog. Sci., 3(1):65-71.

Rezaei A., Akhshabi S.H. and Jamalzadeh H.R. (2011). Sequencing and sequence analysis of Growth Hormone type 1 (GH1) gene homologue in the salmo trutta caspius. Adv. S. Biol., (3): 111-122.

Rezaei A. (2012a). Studies of Cytochrome b nucleotide sequence variation in the Salmo trutta fario. Egypt. Acad. J. Bio. Sci., 3(1):125-131.

Rezaei A. and Akhshabi S.H. (2012). Studies of cytochrome b protein modelling sequence in the Salmo trutta fario and comparing with other salmonids. Egypt. Acad. J. Biolog. Sci., 4(1):1-8.

Rezaei A. (2012b). Studies of Cytochrome b nucleotide sequence variation in the Salmo trutta fario. Egypt. Acad. J. Biolog. Sci., 3(1):125-131.

Rezaei A., Akhshabi S.H. and Jamalzadeh H.R. (2012). The relation between growth hormone $(\mathrm{GH})$ gene and Cytochrome b gene in three salmon types. Egypt. Acad. J. Biolog. Sci., 3(1):133-140.

Rentier-Delruf F., Swennen D., Mercier L., Lion M., Benrubi O., and Martial A. (1989). Molecular cloning and characterization of two forms of trout growth hormone cDNA: expression and secretion of tGH II by Escherichia coli. DNA (N.Y)., 8: 109-117.

Rise M.L., Von Schalburg K.R. and Brown G.D. (2004). Development and application of a salmonid EST database and cDNA microarray: data mining and interspecific hybridization characteristics. G. R., 14: 478-490.

Quillet E., Faure A., Chevassus B., Kreig F., Harache Y., Arzel J., Metailler R. and Boeuf G. (1992). The potential of brown trout (Salmo trutta L.) for mariculture in temperate waters. ICEL Agri. Sci., 6:63-76.

Spidle, A.P. (2001). Fine-scale population structure in Atlantic salmon from Maine's Penobscot River drainage. C. G., 2: 11-24.

Sanchez J.A., Clabby C., Ramos D., Blanco G., Flavin F., Vazquez E. and Powell R. (1996). Protein and microsatellite single locus variability in Salmo salar L. (Atlantic salmon). Her., 77:423-432.

Todd C.M., Walker A.M., Ritchie M.G., Graves J.A. and Walker A.F. (2004). Population genetic differentiation of sea lice (Lepeophtheirus salmonis) parasitic on Atlantic and Pacific salmonids: analyses of microsatellite DNA variation among wild and farmed hosts. Can. J. F. A. Sci., 61:1176-1190.

Terauchi R., and Konuma A. (1994). Microsatellite polymorphism in Dioscorea tokoro, a wild yam species. Gen., 37: 794-801. 
Thorgaard G.H., Bailey G.S. and Williams D. (2002). Status and opportunities for genomics research with rainbow trout. Comparative Biochemistry and Physiology B-Biochemistry \& Mol. Bio., 133: 609-646.

Tsoi S.C.M., Ewart K.V., Penny S., Melville K., Liebscher R.S., Brown L.L., and Douglas S.E. (2004). Identification of Immune-Relevant Genes from Atlantic Salmon Using Suppression Subtractive Hybridization. M. Bio., 6: 199-214.

Verspoor E., McCarthy E.M., Knox D., Bourke E.A. and Cross T.F. (1999). The phylogeography of European Atlantic salmon (Salmo Salar L.) based on RFLP analysis of the ND1/16sRNA region of the mtDNA. Bio. J. L. Soc., 68: 129-146.

Waser P.M. and Strobeck C. (1998). Genetic signatures of interpopulation dispersal. T. Eco. Evo., 13: 43-44.

Wang M.L. Barkley N.A. \& Jenkins T.M. 2009a. Microsatellite Markers in Plants and Insects. Part I: Applications of Biotechnology. Gen. Gen.Gen., 3: 54-67.

Wahs W.S., Bamshad M. and Jorde L.B. (1995). Population genetics of a nucleotide repeat polymorphisms. H. Mol. Gen., 4(9): 1485- 1491.

Weising K., Nybom H., Wolff K. and Kahl G. (2005). DNA Fingerprinting in Plants: Principles, Methods and Applications, CRC Press, ISBN 0-8493-1488-7, Boca Raton, United States. 